This is an open access article under the CC BY-NC-ND license (https://creativecommons.org/licenses/by-nc-nd/3.0/) Issue III, November 2020

ISSN 2707-9481

ISBN 978-601-323-207-2

https://doi.org/10.31643/2020.001

Prof. Dr. Heri Retnawati

E-mail: heri_retnawati@uny.ac.id

Universitas Negeri Yogyakarta

Mathematics and Science Faculty, Indonesia

ORCID ID: 0000-0002-1792-5873
Eny Sulistyaningsih, M.Pd.

E-mail: enylistya@gmail.com

Universitas Negeri Yogyakarta

Mathematics and Science Faculty, Indonesia

ORCID ID: 0000-0002-0992-4600

Dr. R. Rasmuin

E-mail: rasmuinb@gmail.com

Universitas Dayanu Ikhsanuddin Baubau

Southeast Sulawesi, Indonesia

\title{
How to Teach Mathematical Concept Easily? (Learning Trajectory of Two-Variable Linear Equation System Topic in Junior High School)
}

\begin{abstract}
The intention of this study was to find the learning trajectory of two-variable linear equations system in Junior High School. This study was design research using validation study. The participants of this study were Junior High School students in grade IX SMPIT Luqman al-Hakim Yogyakarta Indonesia. Data were collected through observation and interview. Data were analysed using Milles \& Huberman model. Result revealed that the learning trajectory of the two-variables linear equation system were to deepen the mastery of algebra and one-variable linear equation system, model the two-variable linear equation system, solve the experiments, complete the two-variable linear equation using graphs, complete two-variable linear equations by substitution, simple elimination, complex elimination, and mixed method, and solve two-variable linear equation system problems.
\end{abstract}

Keywords: learning trajectory, two-variable linear equation system, design research.

Cite this article as: Retnawati H., Sulistyaningsih E., Rasmuin R. (2020), How to Teach Mathematical Concept Easily? (Learning Trajectory of Two-Variable Linear Equation System Topic in Junior High School). Challenges of Science. Issue III, 2020. Pp.: 5-19. https://doi.org/10.31643/2020.001

Introduction. Mathematics is the study that is important to learn, because mathematics is the basis of any other sciences needed in real life. In addition, learning mathematics also means learning how to solve real-world problems. Mathematics plays a very important role in problem solving activities (Ferreira \& Jacobini, 2009: 3). O'Connell (2007) also mentioned that one of the additional values in studying mathematics is learning problem solving which is as a tool to train students to apply problem solving skills in daily basis. Mathematics is closely related to problem solving or it can be said that the main part of mathematics is problem solving. Pehkonen (1987) also stated that problem solving is one part of the process of applying mathematics.

One of the mathematics materials related to problem solving is two-variable linear equation system. The study conducted by Wulandari \& Harumi (2014) revealed that students' difficulties in solving two-variable linear equation system are students 'misunderstanding to the given problem, students' error in problem solving, and not checking after finding the solution from two-variable linear equation problem. Santoso, Nusantara, \& Subanji (2013: 491) also mentioned that students' difficulties in completing two-variable linear equation are caused by having difficulties in determining the initial condition or initial understanding of the given problem, determining the equation of the given problem, solving the previous equation, interpreting the solution based on the given problem, and checking the solutions. Other difficulties in completing the two-variable linear equation are preparing problem solving, solving mathematic operation and two-variable linear equation problem inaccurately (Wulandari, Hidayanto, \& Dwiyana, 
2016), modelling in the form of variables, applying elimination and substitution method, operating addition and subtraction, obtaining variable replacement value, and changing from variable replacement value to sentence question based on the problems (Dewi, Susanta, \& Listyorini, 2013).

Based on the interview results with teachers, students often directly use substitution and elimination method in solving two-variable linear equation without considering preliminary requirements. The requirement in applying substitution method is to change one of the equations into one of the variables, while the requirement in applying the elimination method is the eliminated variables must have the same coefficient. Students' error in using substitution and elimination method is caused by less attention on the concept formation in students themselves. Students only see the examples and immediately apply the latest two-variable linear equation problems with two-variable linear equation problems that have been resolved previously without considering the process in finding the solution. As a consequence, students will find two-variable linear equation more difficult when encountered the modified problems even though using the same concept.

Students' difficulties in solving two-variable linear equation also can be seen from national examination result. Based on Educational Department data, the average score of national examination on two-variable linear equation in the last four years in Special Regional of Yogyakarta and National can be seen in the Table 1.

Table 1. The Average Score of National Examination on Two-variable Linear Equation

\begin{tabular}{cll}
\hline Year & \multicolumn{1}{c}{ Province Average Score } & National Average Score \\
\hline $2015 / 2016$ & 64,58 & 55,16 \\
\hline $2014 / 2015$ & 57,42 & 57,17 \\
\hline $2013 / 2014$ & 55,84 & 59,22 \\
\hline $2012 / 2013$ & 64,91 & 61,31
\end{tabular}

Table 1 showed the average score of two-variable linear equation in national examination score from 2012/2013 until 2015/2016. The average score decreased from 64.91 to 55.84 in provincial level and 61.31 to 59.22 in national level in the year 2013/2014. Although in 2013/2014 and 2013/2014 were not much different, but by 2015/2016 the average score of two-variable linear equation score in national examinations had increased in the provincial level, but has declined at the national level. In conclusion, the average score of two-variable linear equation between provincial level and national level was not significantly different. Based on Permendikbud No.5 (Mendikbud, 2015: 9), the national examination scores were adequate if the score was greater than or equal to 70, while the average score of the two-variable linear equation in the last four years is less than 70 .

The low average score of students' national examination in the last four years on two-variable linear equation cannot be separated from the learning process which causes students' difficulties in solving two-variable linear equation problems. Some factors causing students' difficulties are students do not understand the purpose of the problem, students do not prepare well before the test, such as daily exam of two-variable linear equation, students do not calculate accurately (Puspitasari, Yusmi, \& Nursangaji , 2015; Rindyana \& Chandra, 2012; Wulandari \& Harumi, 2014), lack of student determination in learning two-variable linear equation (Puspitasari et al., 2015), students do less practice solving various two-variable linear equation problems (Rindyana \& Chandra, 2012) and students do not really understand two-variable linear equation material during the learning process, so that students do not understand the concepts and principles of two-variable linear equation (Puspitasari et al, 2015; Wulandari \& Harumi, 2014).

Various factors that can cause the low score of national examination on two-variable linear equation can be overcome by implementing focused learning process regularly. The learning process is conducted by considering the learning trajectory, such as in connecting one concept to another. The mathematics learning process must be systematic, sequential, and based on previous learning experiences (Hujodo, 1998). The common mistake that usually found in the learning process is that the learning of certain concept is still partial, even though one concept and other are in fact connected. Hence, it is necessary to construct learning trajectory that can be used as local theory in the two-variable linear equation learning process. In conclusion, this study aims to find the learning trajectory of twovariable linear equation in grade VIII in Junior High School.

Methods. This study is design research using validation studies (Nieven, Mc Kenney, van den Akker, 2006: 152) which consists of preparing for the experiment phase or preparation and design phase, design experiment, retrospective analysis (Greivemeijer \& Cobb, 2006). The hypothesis is stated in the first phase. The learning trajectory in two-variable linear equation which is hypothesised consists of modelling and deepening algebra and one-variable 
linear equation system, modelling two-variable linear equation system, solving problem by trial and error, completing two-variable linear equation with graphs, completing two-variable linear equation with simple substitutions, solving problem with simple elimination, solving problem with complex elimination, completing problem in a mixed method, and solving two-variable linear equation problems.

The experiment phase is conducted by testing the learning trajectory in mathematics learning. The learning trajectory is structured by considering the prerequisite concepts required in two-variable linear equation learning. The hypothesis of learning trajectory was tested in IX grade of junior high school. The participants of this study were 14 female students. Data were collected by documentation of learning trajectory design, and observation and documentation of learning implementation. Documentation of learning implementation included the students' worksheet. Then, retrospective analysis was performed. Data were analysed using Milles \& Huberman model using reduction, display, and verification steps. The analysis results were then described to obtain the learning trajectory of two-variable linear equation for junior high school based on the design and test.

Findings. Result shows that junior high school students need to master preliminary materials before start learning two-variable linear equation. The prerequisite materials on the two-variable linear equation are algebra and one-variable linear equations. These two prerequisite materials become the basic material and can be used to facilitate students in mastering two-variable linear equation. Therefore, it is necessary to create a clear and directed learning trajectory accordingly with learning objectives. This study also hypothesizes the learning trajectory considering the cognitive load to reduce the students' difficulties in mastering two-variable linear equation material. The hypothesized learning trajectory is to model and deepen the mastery of algebra and one-variable linear equation, model two-variable linear equations, complete the problem using trial and error, complete two-variable linear equation using graphs, complete two-variable linear equation using simple substitutions, solve the problem using simple elimination, conduct complex elimination, solve the problem using mixed method, and solve two-variable linear equation problem.

The two-variable linear equation learning process does not sufficiently use designed lesson plan. Learning process will be more effective if it is supported by supporting learning instruction on two-variable linear equation, including lesson plan and worksheet. Lesson plan and worksheet preparation are constructed based on the designed path. Learning process can be carried out using problem-based learning (PBL) which accompanied by worksheet. Worksheet is constructed in English, because the participants are students in international school. The learning process, however, was conducted using bilingual (English and Bahasa). Worksheet is designed using interesting images downloaded from the internet (with sources included) and also adapting the latest issues from PISA. Then, the hypothesized learning trajectory are tested to junior high school students using the designed learning plan and worksheet. The results of the trial and analysis of each step are presented as follows.

The first step in the learning trajectory of two-variable linear equation in this research was to deepen the mastery of student's algebraic modelling. In this step, students were invited to model algebraic problems, perform algebraic operations such as addition, subtraction, multiplication, and division. This concept had actually been studied by students in grade VII, but this concept needed to be reminded to reinforce students' conceptual understanding.

Figure 1. S1's Work in Algebra

Look at the cages. Can you calculate the number of animal in the cages?

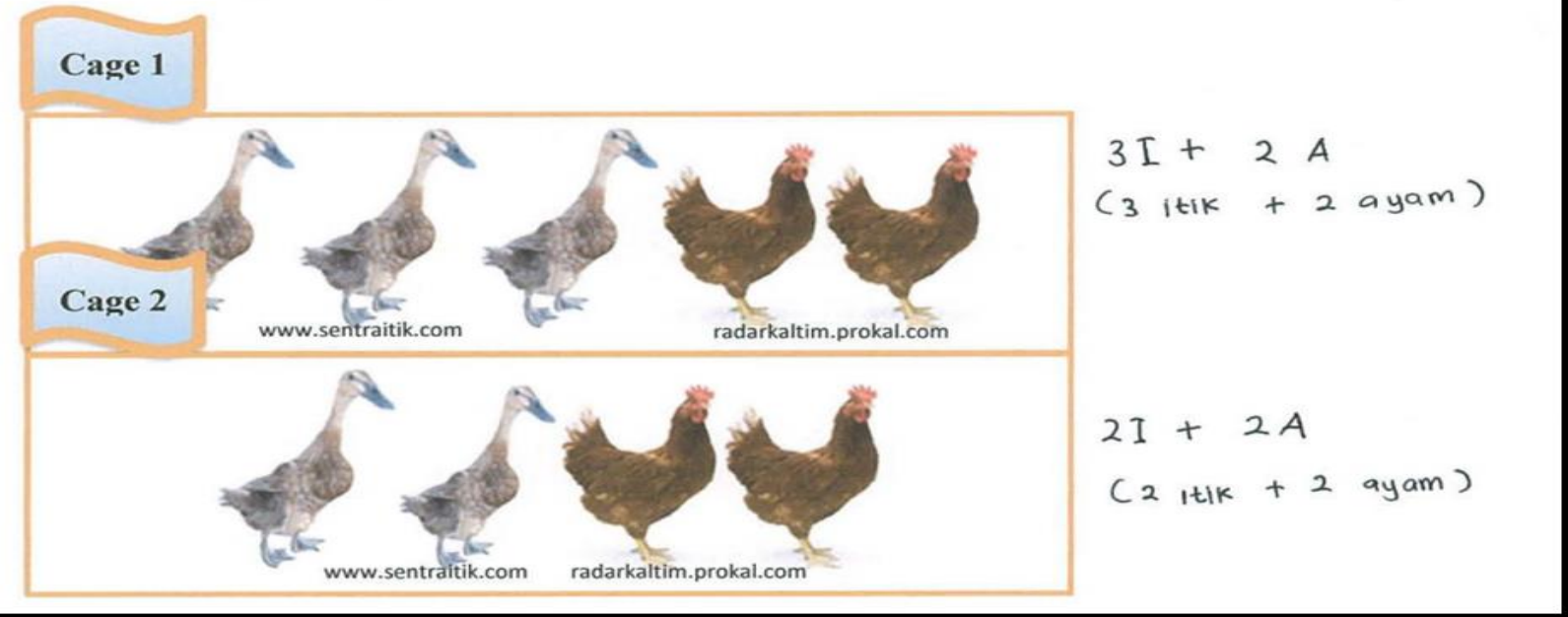


Figure 1 illustrated that students had been able to model algebraic modelling from real-world problems. The first problem given to students in the form of pictures that could help students understand one-variable linear equation, especially for students who have not really understood the concept. The modelling made by students based on the given problem also showed that students had understood the existence of two variables which represent the different things that could not be counted into one. One variable represented duck and another variable represented chicken. After modelling the problem, students could perform operations on algebraic forms, such as addition. Figure 2 illustrates S9's answer.

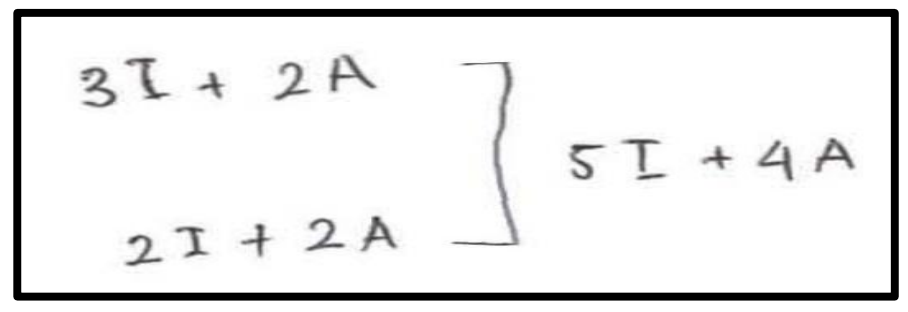

Figure 2. S9's Answer in Determine Algebraic Form

Figure 2 showed that student already understood if there were two equations using two different variables, the calculation could only be calculated for the same variable. After mastering the operation of the algebraic modelling, students solved one-variable linear equation problem. Therefore, it can be concluded that solving onevariable linear equation becomes easier when using contextual problem.

Silva had bought a pack of chocolate. He paid $\$ 12$ for 1 pack of chocolate. After he arrived in his home, he opened the pack and he saw there was 6 bars of chocolates. Can you help Silva to determine how much does he should pay if he will buy 1 bar of chocolate?

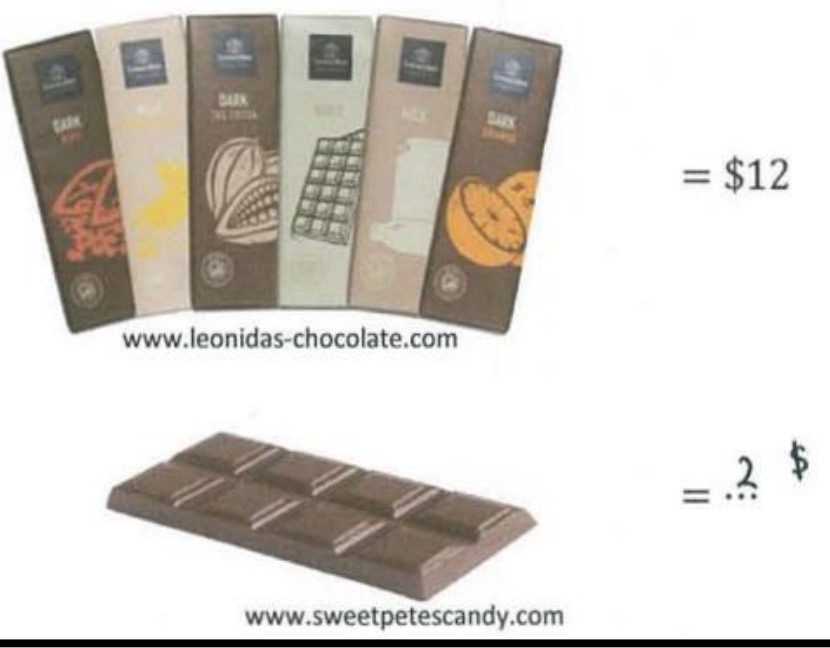

Figure 3. S2's Work in the First One-variable Linear Equation Problem

The second problem given to students was the problem which presented in narration. In this case, students not only reused the concept of algebra that had been mastered but also practiced to understand the problems in the 
context of the given problem. In this problem, students still used the concept of one variable-linear equation system. Therefore, students were able to solve one-variable linear equation easily using contextual problem.

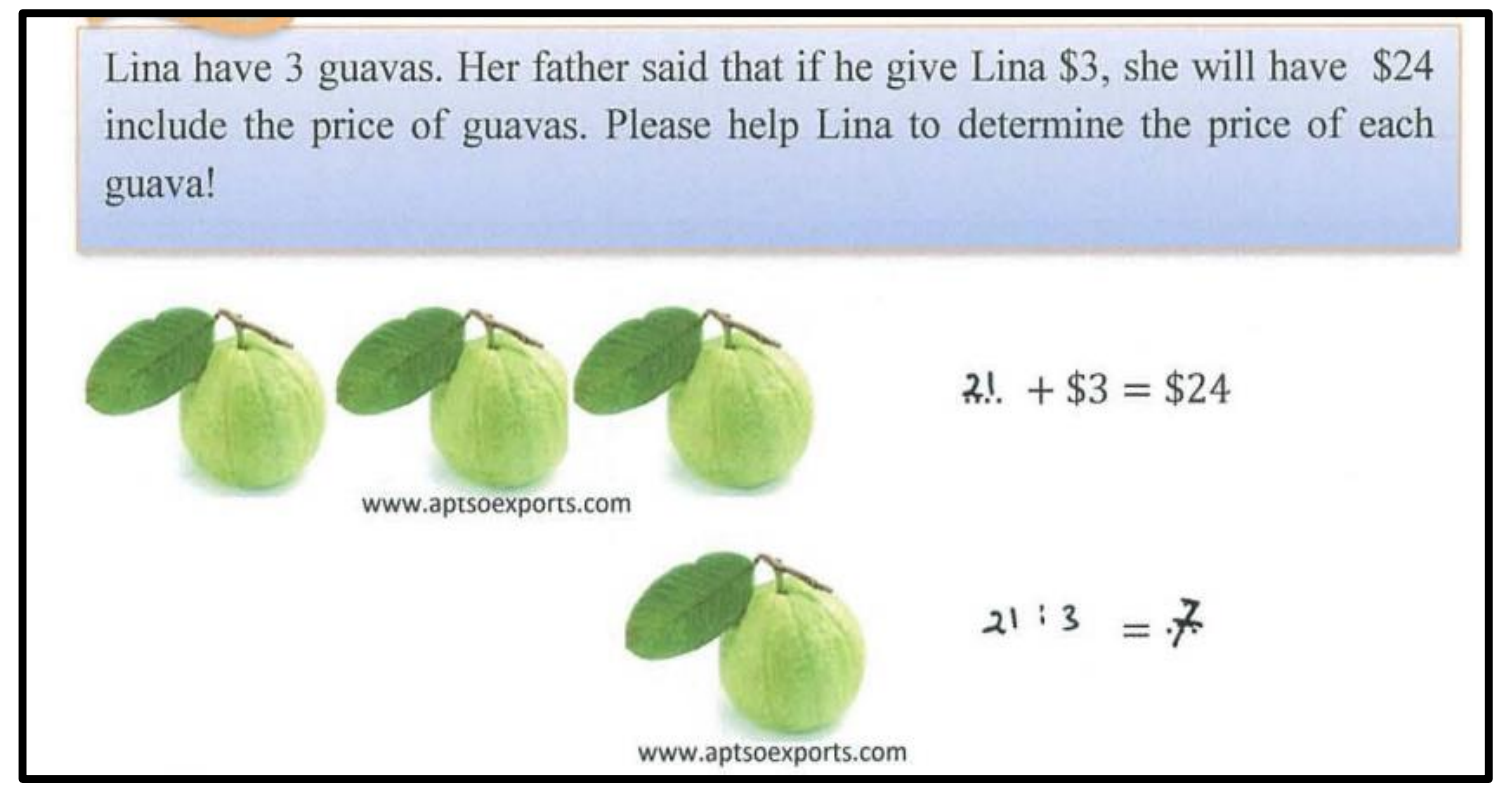

Figure 4. S6's Work in Second the One-variable Linear Equation Problem

Students' ability to solve one-variable linear equation presented in narration using contextual problems also could be seen in the second problem shown in Figure 4. Students were able to solve the one-variable linear equation problem correctly. In the first and second problems, students were still given pictures to help students understand the problem using narration. The second problem, however, had higher difficulty level than the first problem. Figure 4 illustrates that students were demanded to better use their understanding of algebra in solving the problem.

The next step in the two-variable linear equation learning trajectory was to model some two-variable linear equation problems. Modelling the encountered problems into two-variable linear equation would be easier when using contextual problem, for example the book was encoded into B and pencil was encoded into P. And then, two-variable linear equation was solved using trial and error. Using this equation system, students used various numbers indicating the price of books and pencils until they obtained the correct number and fulfil the equation system. The example of model preparation and student trial and error results are presented in Figure 5.

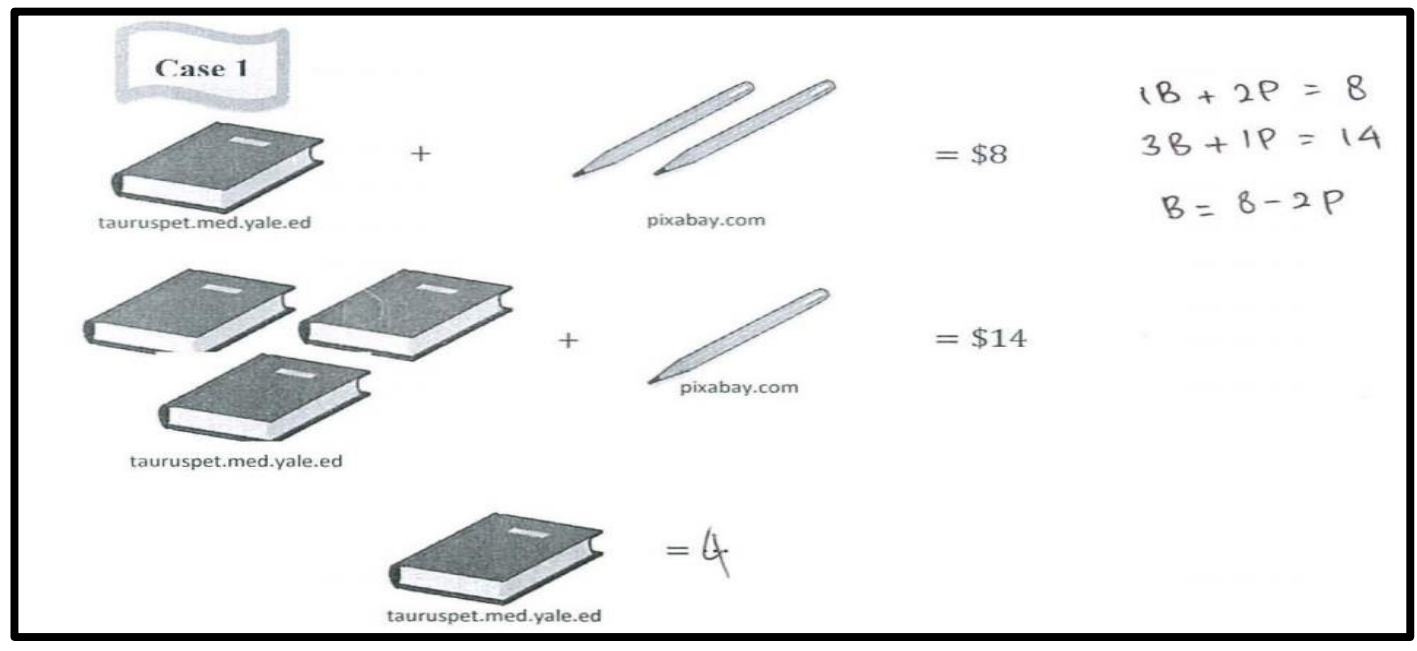

Figure 5. Trial and Error Method in Solving the Two-variable Linear Equation Problem 
Figure 5 showed the two-variable linear equation using simple numbers, so that students were able to solve it by trial and error. Trial and error, however, also required high- level of reasoning. It meant that not all students could solve the problems quickly and accurately, even though using simple numbers and pictures. Students also unable to solve the more complex two-variable linear equation problems using trial and error. A student mentioned that "... the first case is still easy but others are difficult, especially using big number. Is there any other easier way?"

The question could be answered by taking the student to the two-variable linear equation concept with the graph. The problems used relate to the object in daily life. Problems were presented in narration and picture to facilitate students in understanding the problems. Based on the problem, students were asked to create two-variable linear equation model. Similar to the previous trial and error method, the student placed the pair of points in the first equation and the second equation, then looks for the same value in the first and second equations. The modelling results are presented in Figure 6 and pair of points shown in Figure 7.

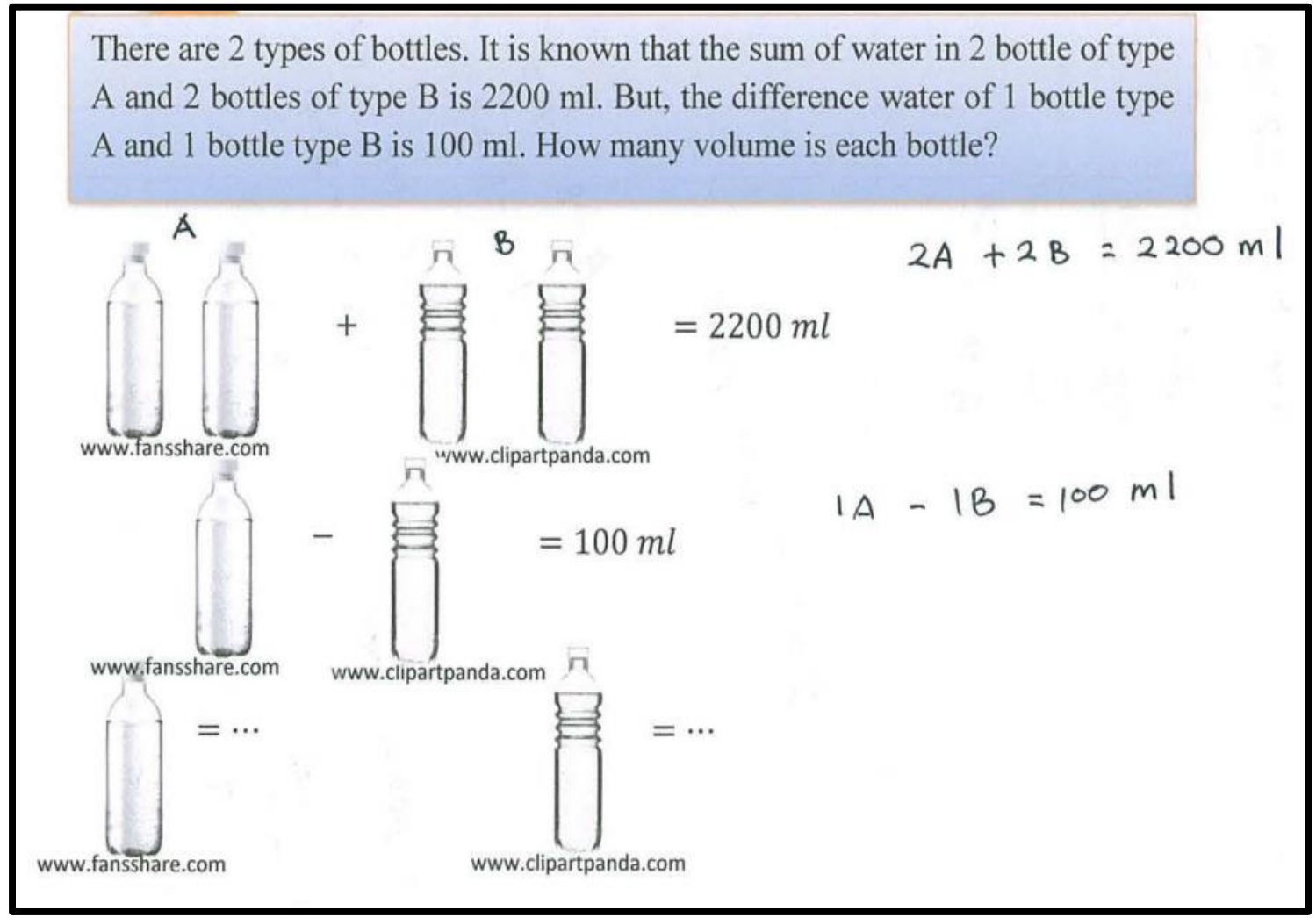

Figure 6. S8's Two-variable Linear Equation Model

Figure 6 showed that students had been able to model two forms of two-variable linear equations. Students were able to understand the use of two variables to represent two different things. Variable A was for the first bottle and variable B was for the second bottle. After students write two-variable linear equation model, students proceeded to find the coordinate points that would be used in the graph making. The coordinate point was obtained by experimenting with number which was also the solution of the first two linear equations as the first line of the graph and the second equation as the second line. Figure 7 illustrates student's work in pairing the solution points as the coordinate points.

Figure 7 illustrates that student had been able to use a trial and error method for a larger number than the previous problem which used the simpler number. It also indicated that students had understood the relationship between variables A and variable B on each two-variable linear equations. Using these points, students could describe that variables in the graph presented in Figure 8. 


\section{Based on case 3,}

a. make system of linear equation in two variables from the case!

b. Using each of the system linear equation, can you find the coordinate points?

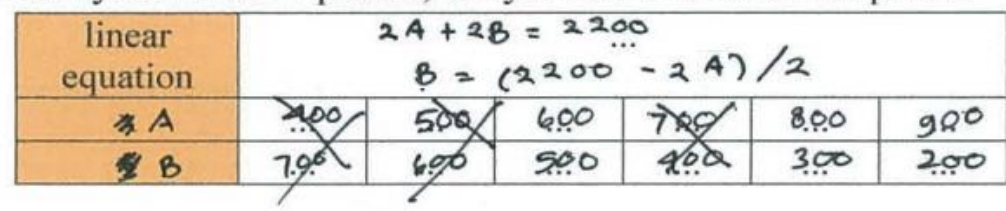

\begin{tabular}{|c|c|c|c|c|c|c|}
\hline $\begin{array}{l}\text { linear } \\
\text { equation }\end{array}$ & \multicolumn{5}{|c|}{$\begin{array}{l}A-B=100 \\
B=A-100\end{array}$} & \\
\hline *A & 400 & $500 /$ & 600 & 700 & $\ldots$ & $\ldots$ \\
\hline$\triangle B$ & 300 & Aap & 5.00 & 400 & $\ldots$ & .. \\
\hline
\end{tabular}

\section{c. Using coordinate point, make the graphs and find out the intercept as the solution!}

Figure 7. S14's work in pairing the solution points

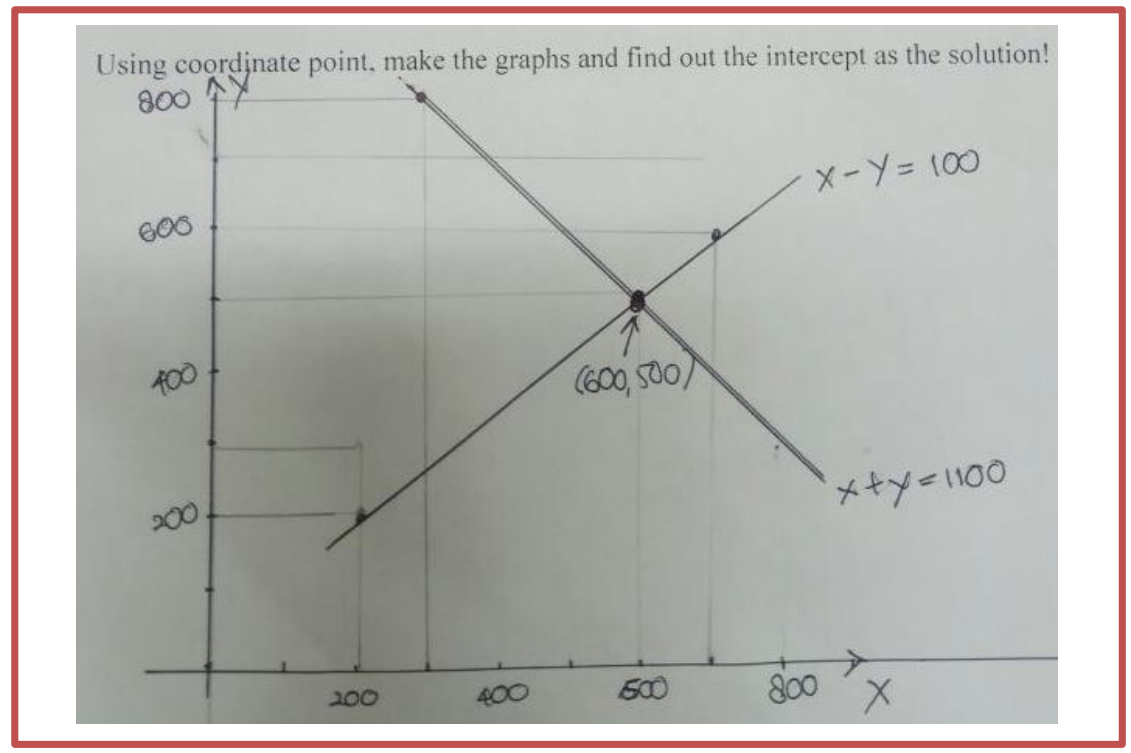

Figure 8. S4's in Student's Responses Using Graph

Figure 8 showed that the intersection of the first line (from the first two-variable linear equation) to the second line (from the second linear equation of the two variables) was the solution of the two-variable linear equation. Based on the picture, the two lines intersected at the point $(600,500)$. It meant that the solution of the two-variable linear equation was $\mathrm{A}=600$ and $\mathrm{B}=500$. In other words, the two-variable linear equation would be fulfilled when the volume of bottle A was $600 \mathrm{ml}$ bottle and the volume of bottle B was $500 \mathrm{ml}$. The next step in the two-variable linear equation learning process was to complete the two-variable linear equation using simple substitutions. Problem was presented in the illustration of sports equipment. Students were required to model the given image into the form of two-variable linear equation system. Figure 9 depicts student's answer in solving the problem.

Figure 9 showed that student used two variables, $\mathrm{B}$ for the ball and $\mathrm{T}$ for the stick, on the baseball game. Result illustrated that students modelled the given problem in two-variable linear equation into $2 \mathrm{~B}+\mathrm{T}=24$ and $2 \mathrm{~T}$ $=20$. The equation was simplified by dividing the two equations from second equation, $\mathrm{T}=10$. Then, student substituted the results in the first equation. The result of substitution showed that $\mathrm{B}=7$. In conclusion, student could answer the price for one ball and one stick, so that the total price was $17 \$$ which is obtained by calculating $10 \$$ for a ball and $7 \$$ for a stick. 


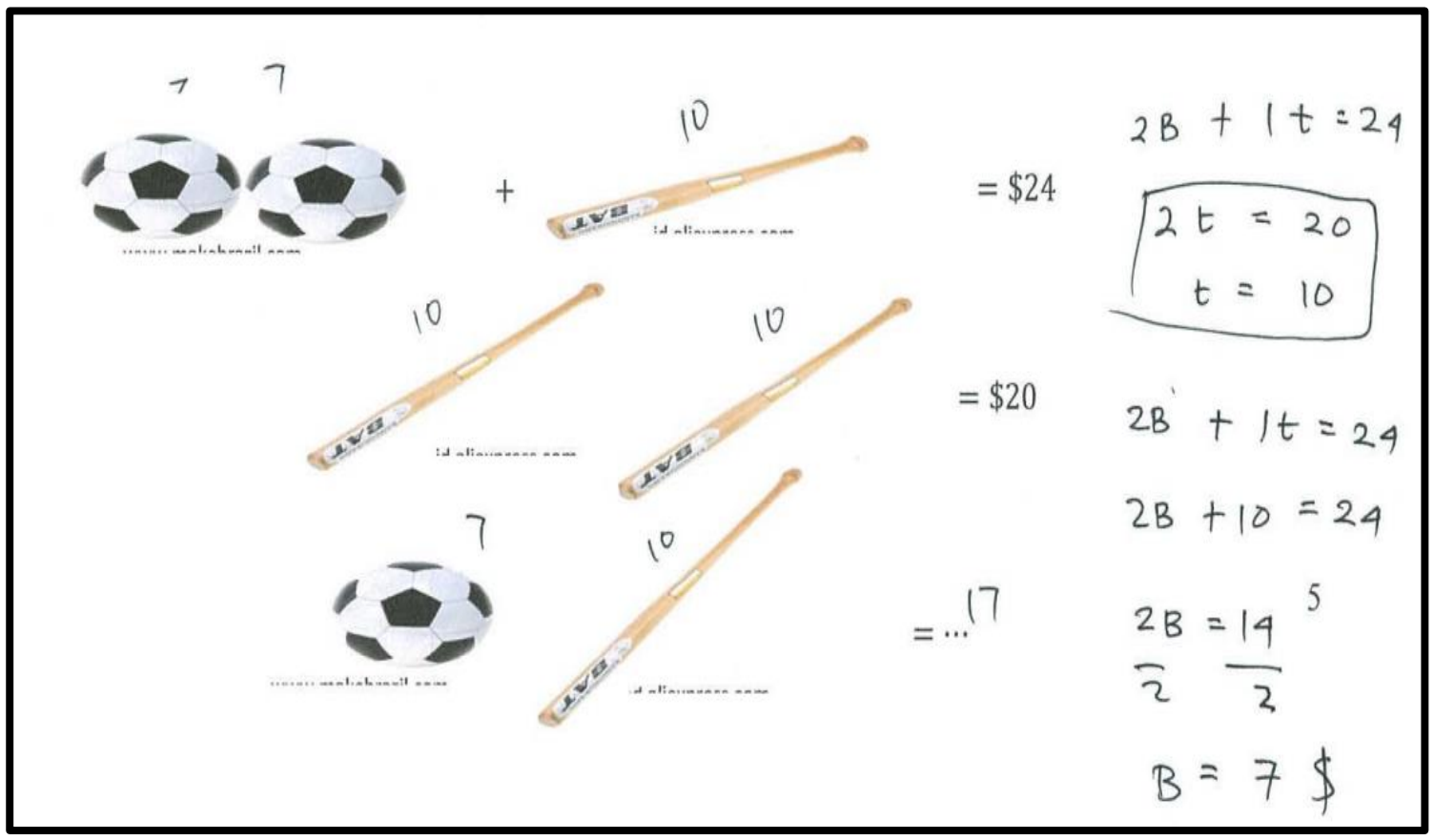

Figure 9. S2's Work Using Substitution

After students capable of solving two-variable linear equation problems using graphs and substitutions, the next step was providing two-variable linear equation problems to students to be solved using elimination. Problem was also presented in pictures which could help the students to understand it. The elimination concept was given in order systematically. The student's answer is illustrated below.

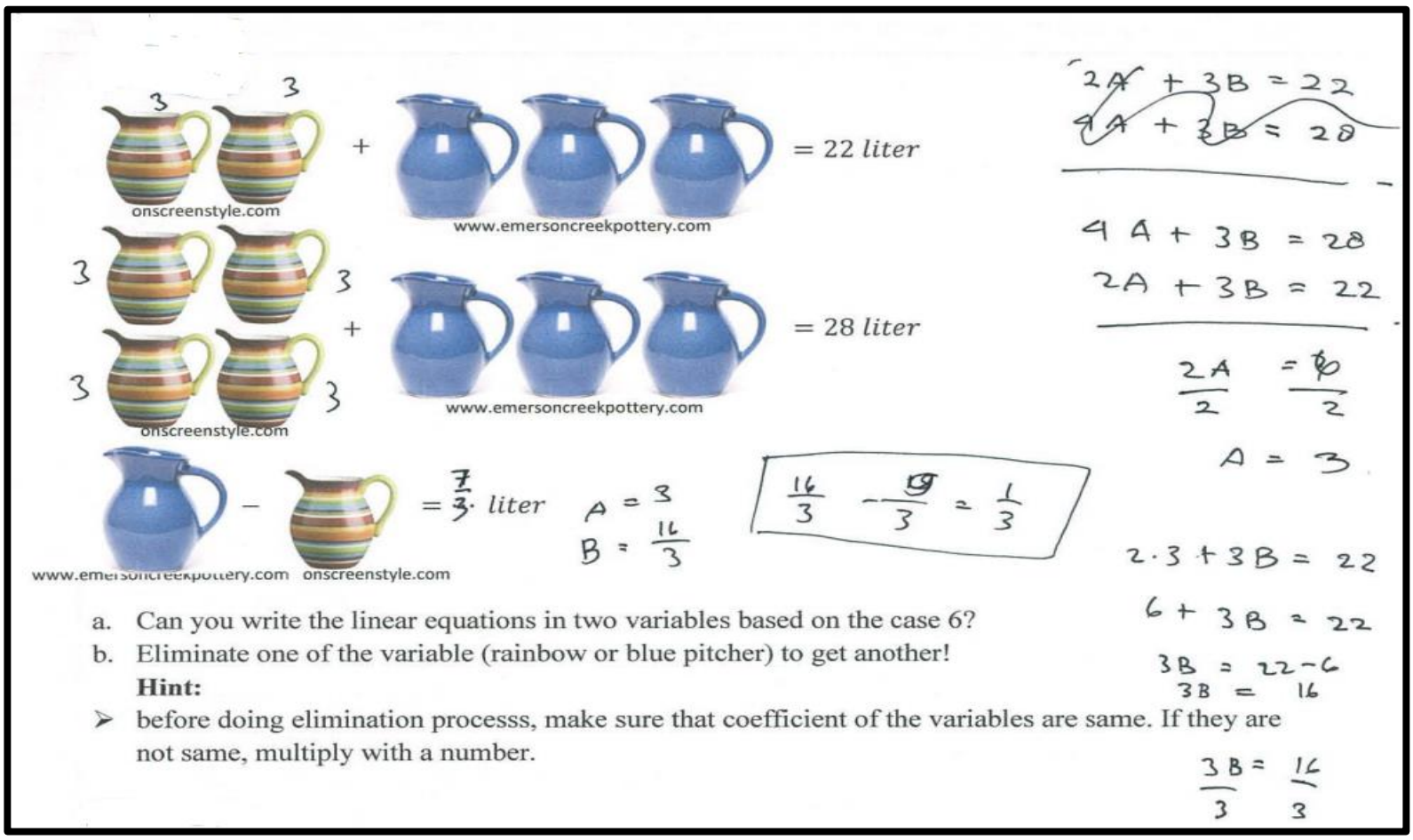

Figure 10. S2's Work Using Simple Elimination 
Student used two variables for the given problem in Figure 10, variable A for the first pitcher and B for the second pitcher. The concept of elimination in this problem was still simple, because students had one variable that has the same coefficient. It allowed students using elimination, because students did not need to multiply with a certain number to get the same coefficient on one variable. Result showed that the volume of pitcher A was 3 litter. Based on that result, students substituted the value of $\mathrm{A}$ in one equations to obtain a value of $\mathrm{B}$. Result showed that the volume of pitcher B was 16/3 litter. So, it can be concluded that student could solve the problem by looking for the volume difference between the first and second pitcher which was obtained $7 / 3$ litter.

Figure 10 showed that students had understood the elimination concept, so that students were able to solve the given problem. Figure 10 also showed that students combine the elimination and substitution concept. The combination of both concepts were called mixed concepts. The elimination concept was used to obtain a value from certain variable, then proceeded by using substitution concept to obtain values from other variables as had been done in the previous problem. In addition, the problem also used more complex algebraic concepts than thebprevious problem, because the answer was not an integer. In conclusion, students' ability to count using fractions is visible.

The next step in two-variable linear equation learning process was still using the elimination method but using more complex problems. The level of difficulty was on the elimination step to get the value of a variable. The following problem involved the weight of two types of fish. Problems and solutions are illustrating in Figure 11.

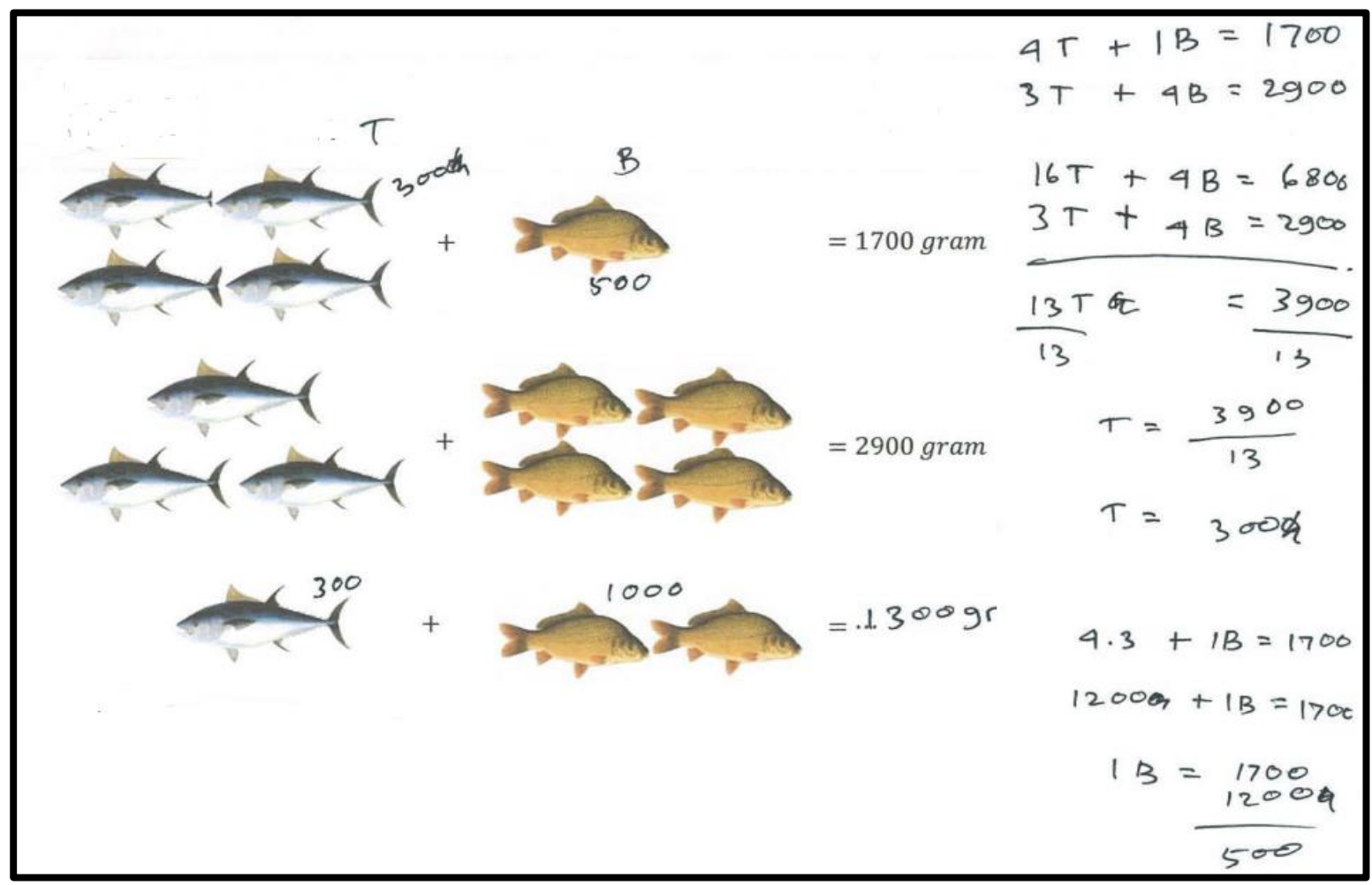

Figure 11. S1's Work Using Complex Elimination

Figure 11 showed that students could solve the problem, even though the difficulty level of elimination method application was more complex. In addition, the number used was also greater than the previous problems. Students used the T variable for the first fish type and use B variable for the second fish type. The coefficients of the two variables either in the first or second equations were not the same. Therefore, before students apply the method of elimination, student had to multiply the equation by a certain number so that the same coefficient will be generated for one of the variables to be eliminated. In Figure 11, the student chose to eliminate variable B. The student's step to get it was to multiply 4 in the first equation to obtain the same coefficient between the first and second equations. Furthermore, students could do the elimination as in previous problems that was by eliminating one of the variables and get the value for another variable. The result of elimination on variable B was obtained by value for variable $\mathrm{A}$ that is 300 . The value of $\mathrm{A}$ was continued to be substituted on one equation so that the obtained value for variable B. 
Variable B obtained was 500. Based on these values, the student could solve the problem calculating the weight of the first fish type and the second type, so that the results was 300 grams. The student's ability to solve problems in figures 10 and 11 showed that students had fully understood the concept of two-variable linear equation using simple or complex elimination methods and mixed methods involving elimination and substitution.

The last step in two-variable linear equation learning process was solving two-variable linear equation problems. This last step was conducted when students had understood previous concepts such as two-variable linear equation completion using graphical methods, substitutions, simple elimination, complex elimination, and mixed methods. In this part, the given problem was more complex than the previous one. The problem in the last step was no longer using pictures to illustrate the problem explicitly, but using narration that required logical reasoning. At this stage, students were not given instructions to solve the problems as given it the elimination method. The first twovariable linear equation problem and answer is illustrated in Figure 12.

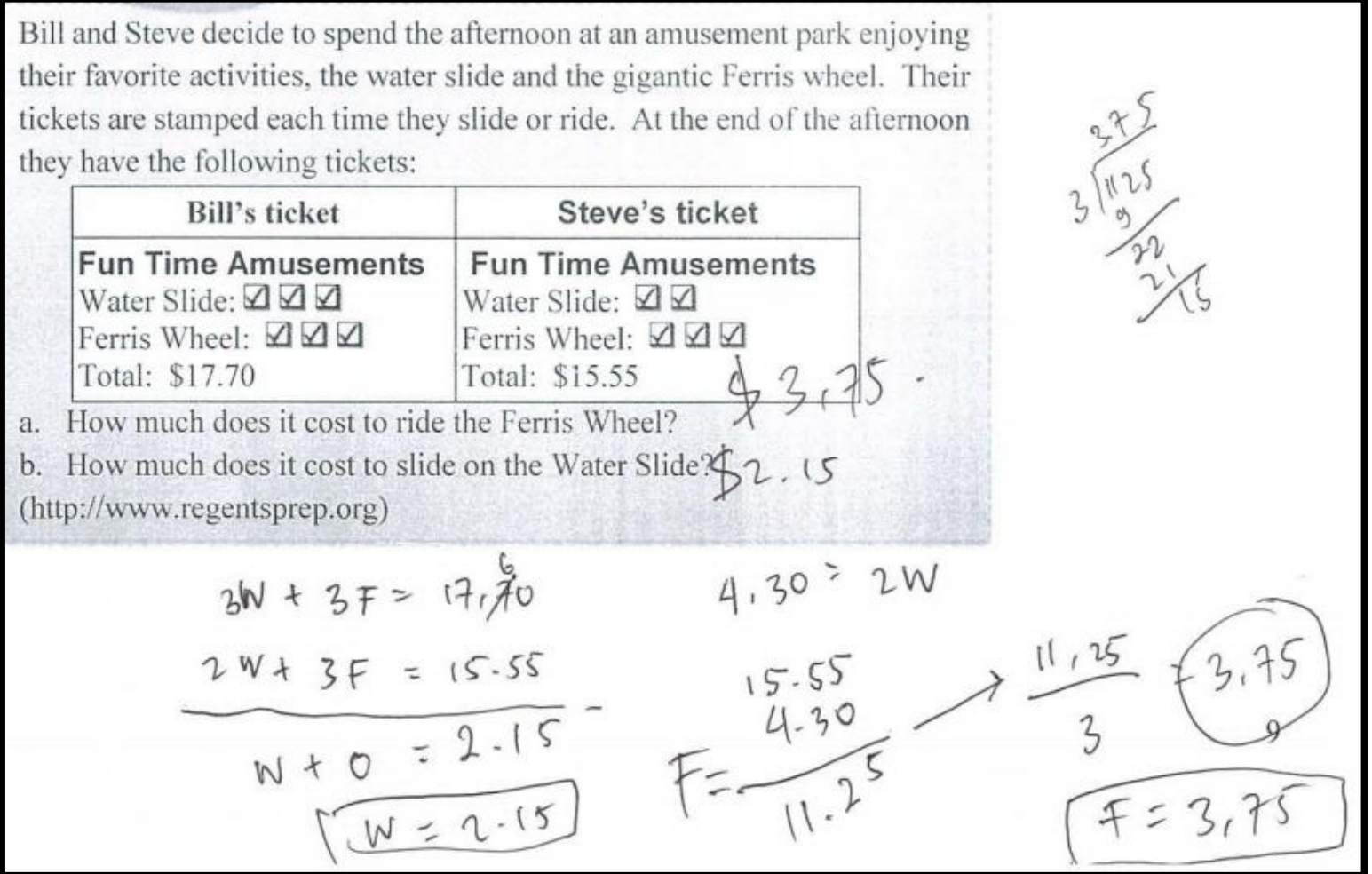

Figure 12. The Solution of First Two-variable Linear Equation Problem

The problem given in Figure 12 asked students to understand and answer two questions. Problem solving was not limited to graphical methods, substitutions, or elimination. Figure 12 illustrated that student chose to use a mixed method. Students used variable $\mathrm{W}$ for water slide and $\mathrm{F}$ for Ferris wheel. The first equation obtained from Bill's ticket was $3 \mathrm{~W}+3 \mathrm{~F}=17,7$, while the second equation obtained from Steve's ticket was $2 \mathrm{~W}+3 \mathrm{~F}=15,5$. A simple elimination was used to get one of the variable values. A simple elimination was conducted by eliminating the variable $\mathrm{F}$ that had the same coefficient to obtain the value $\mathrm{W}=2.15$. Furthermore, the value of $\mathrm{W}$ was substituted on one of the equations, so that the value obtained was $F=3.75$. Although the elimination method used was a simple elimination, but solving the problem involves the operation of counting the decimal number. After the students got the value for each ticket, students could answer two questions asked on the given problem which were the price for a Ferris wheel ticket and the price of a water slide ticket.

Furthermore, students were given other more complex problems. The following problem was one of the twovariable linear equation problems used in in the latest PISA problems. Students were asked to calculate the height of the hexagon and rectangular arranged according to two other arrangements that had been given. Figure 13 depicts student's answer on solving the problem. 
Figure 13 depicted that student also used mixed method. The two variables used were A and B, each representing rectangular and hexagon. The first equation was obtained from the first construction which consists of three hexagons and three rectangles in 21 meters in height, so that the equation was $3 \mathrm{~A}+3 \mathrm{~B}=21$. The second equation was derived from the second construction which consisted of three hexagons and two rectangles totalling 19 meters in height, so the equation was $3 \mathrm{~A}+2 \mathrm{~B}=19$. The answer used simple elimination, because the hexagon in both equations was the same, so the value multiplication was not necessary. The result of the elimination of both equations was $\mathrm{B}=2$. In other words, the height of a rectangular building was 2 meters. Based on the value of $\mathrm{B}$, then the substitution was conducted to find the value of $\mathrm{A}$, which was $\mathrm{A}=5$. So the height of a hexagon was 5 meters. After the value of the two variables was obtained, students solved the problem by calculating the height of a hexagon and two rectangles to obtain the total height which was 9 meters.

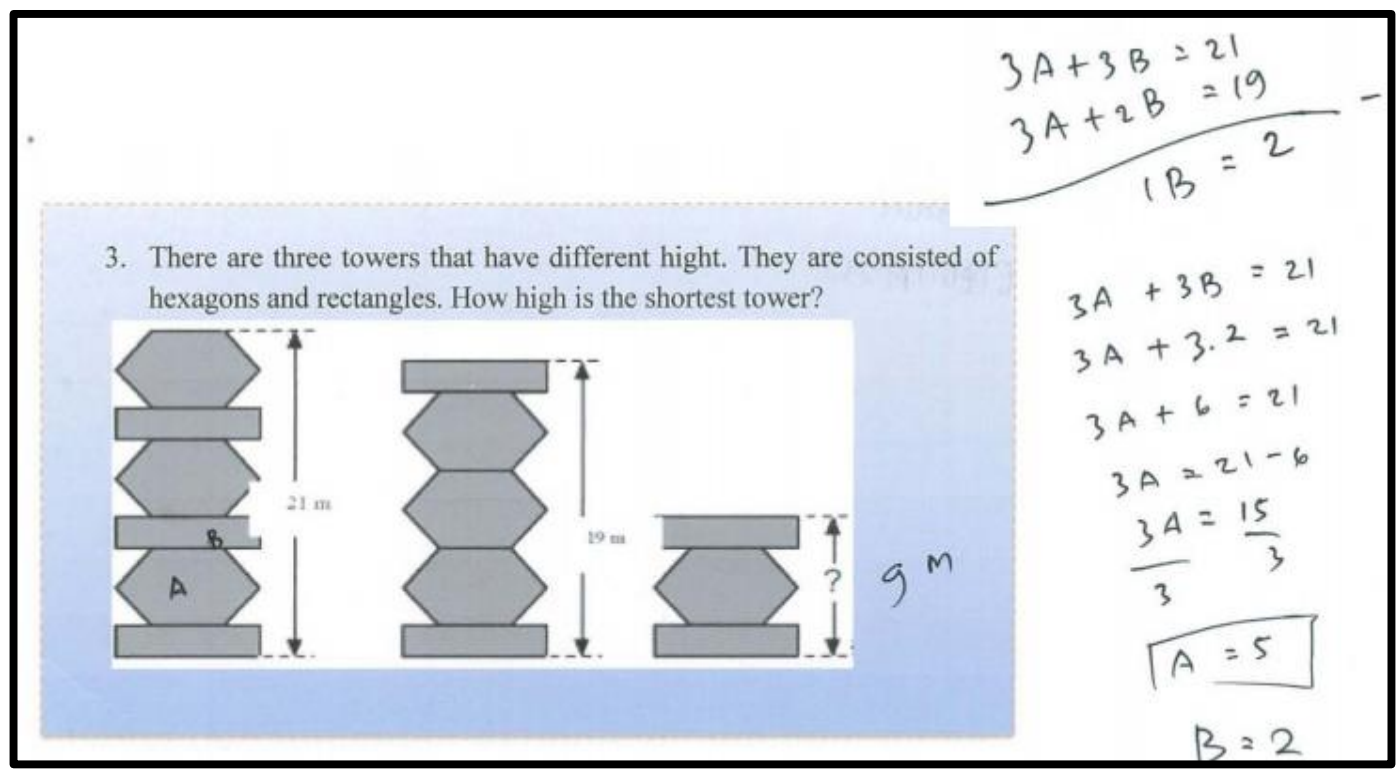

Figure 13. The Solution of the Second Two-variable Linear Equation Problem

Students' understanding of two-variable linear equation material would increase as students encounter various two-variable linear equation problems. Therefore, in the last step of two-variable linear equation learning process, problem solving, there were three kinds of problems that must be solved by students. The third problem was only presented in narration. Students not only understood the problem but also analysed the variables which would be used and resolved as well as the core issues that must be solved according to the question. Student's answer on the third problem is shown in Figure 14.

The problem solved by students in figure 14 was more complex than the previous problem. Students solved the value of each variable which had been also added by the price for $1 \mathrm{~kg}$ of cat food. The final question on the problem did not lead directly to the value of the variable that would be directly answered when the two variable values were obtained. First, student understood the problem and then proceeded by analysing which part that would be represented by the variable. The variables were P for Persian cat and A for Angora cat. Furthermore, student must be able to write down two-variable linear equations of the given information. After two-variable linear equation was obtained, students began to determine the value of one of the variables. Figure 14 showed that student used substitution, because the first equation was already in one variable, $\mathrm{P}=\mathrm{A}+10$. The substitution of the value of $\mathrm{P}$ in the second equation was $2 \mathrm{P}+3 \mathrm{~A}=620$ and $\mathrm{A}=120$. The result was then substituted on the first equation, so that $\mathrm{P}$ $=130$. Another difficulty level on this problem was the different time units. The question provided the information about cat food in a day, but students were asked the total cost for cat food in a week. This part required precision and students' good understanding. After students got the value of each variable, then students proceeded by calculating both equation by seven (one week equals to seven days). The result was 1750 grams or $1,75 \mathrm{~kg}$ of food in a week. In 
conclusion, to answer the question, students multiplied the amount of food needed with the price of food per $\mathrm{kg}$ so that the price earned was $\$ 35$.

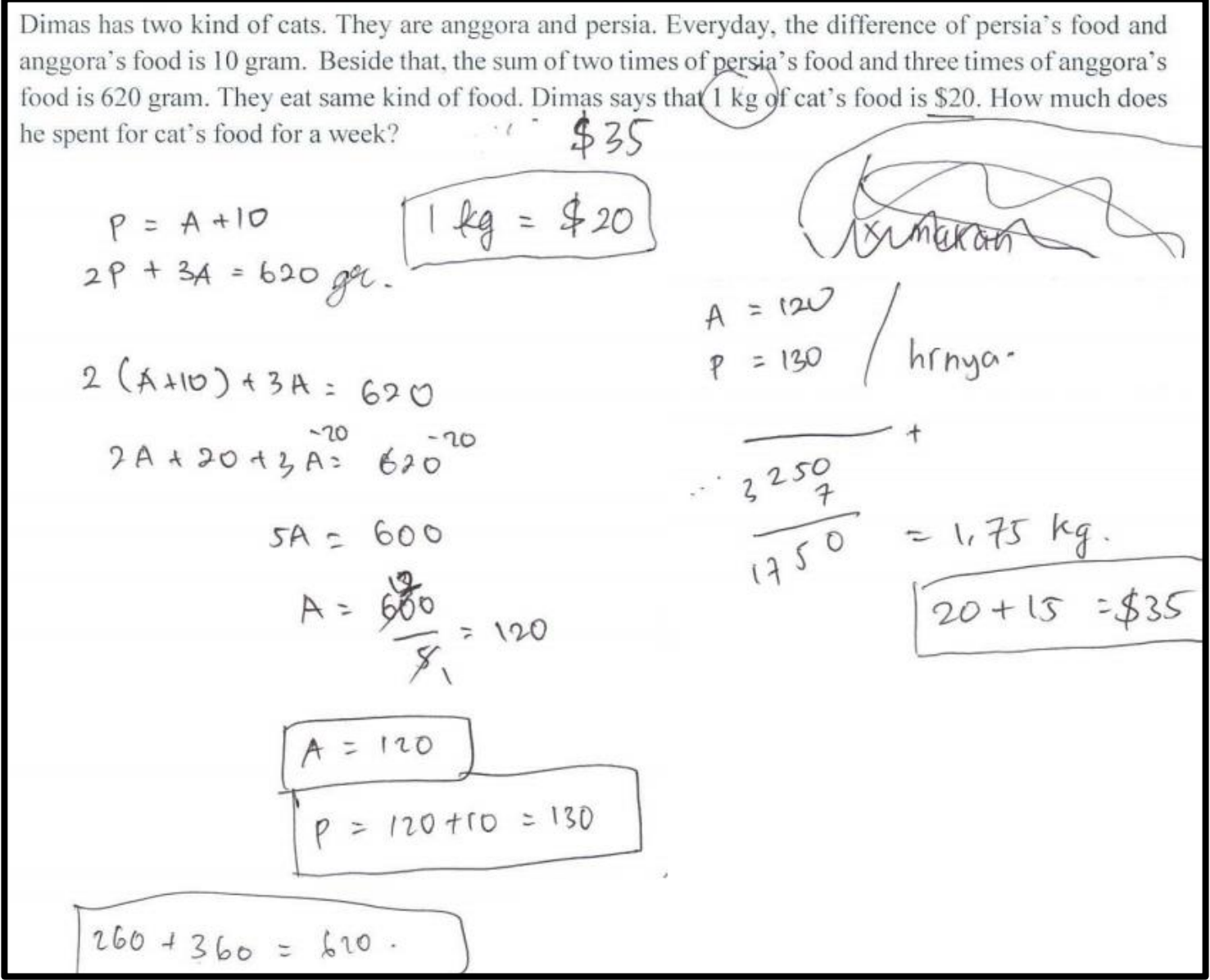

Figure 14. The solution of the Third Two-variable Linear Equation Problem

Discussions and conclusions. Two-variable linear equation for junior high school is one of the materials that requires more effort from teachers as well as students to understand it. It can be seen from the national examinations result that is low in last few years. Due to this condition, more attention is needed to the process of learning on twovariable linear equation material in order to help students to understand it. The learning process based on the progress of students' understanding which can be used in selecting and arranging instructional activities can create a more effective mathematics learning environment (Clements \& Sarama, 2013: 122). The learning process that constructs an inseparable link between psychological and instructional development is called learning trajectory (Clements \& Sarama, 2004: 83). Learning trajectory is related to student learning objectives, students' comprehension, problems encountered that require students to master new knowledge or concepts, and correct inaccurate understanding (Daro, Mosher, \& Corcoran, 2011: 18). In addition, Arends \& Kilcher (2010: 38) also recommended learning process by making planning and learning strategies that can connect the prerequisite knowledge with new material to be studied. Therefore, it is necessary to design learning strategies and its learning trajectories. The learning trajectory in this study focus on modelling and understanding algebra and one-variable linear equation system, modelling two-variable linear equation system, solving problem by trial and error, completing two-variable linear equation with graphs, completing two-variable linear equation with simple substitution, solving problem with simple elimination, complex elimination, and mixed method, and solving two-variable linear equation problems.

The first step in learning trajectory is modelling and mastering algebra and one- variable linear equation system. Algebra and one-variable linear equations system are the prerequisite materials that students must master before starting to learn the two-variable linear equation. Prerequisite materials are used as the basis for more complex 
material. Clements \& Sarama (2013) mentioned that the progress of children in the learning process is strongly influenced by their first educational experience. In addition, Arends and Kilcher (2010: 27) stated that knowledge of the initial material is one of the important factors in determining what students will learn. Therefore, teachers should also have the initiative to check students' understanding of the prerequisite materials which have to be mastered before learning two-variable linear equation. Teachers also have to provide direction and guidance for students who are still weak in understanding the prerequisite material (Daro et al., 2011). In fact, there are few students who still do not have the right concept on the prerequisite material. It becomes one of the causes of students' difficulties in understanding and solving two-variable linear equation problems. One alternative to overcome that problem is by recalling the prerequisite material needed in studying two-variable linear equation. Aside from mastering the prerequisite materials, learning trajectory that has a clear flow will also help students understand two-variable linear equation concept. Hujodo (1998) stated that the process of studying mathematics must be systematic, sequential, and based on previous learning experiences or prerequisite materials. In addition, Daro et al. (2011) also stated that teachers are responsible for monitoring students' understanding and learning and also providing follow-up to monitoring results by keeping learning activities in line with the learning objectives, or returning learning that has diverged back to suit its objectives.

Despite of prerequisite materials, learning approach is also need to be considered in learning two-variable linear equation. The approach chosen in two-variable linear equation learning process is problem based learning (PBL) approach. The PBL approach is a learning approach that begins by providing real- world problem to students (Tan, 2004). The aim of PBL approach is to make students get better understanding in two-variable linear equation concept in real world and its applications.

The next step in learning trajectory of two-variable linear equation is to model the two-variable linear equations. When students have been able to model a one-variable linear equations system, it means that student have understood the meaning of variable and its application. Then, students learn to add one different variable in the equation, so that it becomes two-variable linear equation. Ferreira and Jacobini (2009: 37) mentioned the importance of students' ability in modelling the problem, that modelling ability in mathematical problem is essential to simplify and solve real problems. After students capable of modelling the given information into two-variable linear equation, students try to solve it by trial and error. It trains students' cognitive abilities. In addition, by using trial and error, students will understand which one is the problem completion and not. When students solve the problem using trial and error, not all students get the solution right away. It takes a considerable amount of time and also possibly makes students feeling discouraged when they have trouble in finding solutions. The next step in learning trajectory is introducing how to solve two-variable linear equation problem using the graph method. Study conducted by Seifi, Haghverdi, and Azizmohamadi (2012) revealed that making picture or graph can help students overcome their difficulties in learning mathematics. By making a graph based on coordinate points that have been made, students will be easier in determining the solution of two-variable linear equation problems. The solution is located at a point cut between two lines formed from the two equations of two variables.

The next step in two-variable linear equation learning trajectory after solving the problem using graphical method is solving two-variable linear equation using substitution method which substitutes one equation in a variable and determining the value of those variables. Substitution methods have a higher difficulty level than graph methods because it takes more students' algebraic abilities than graph methods. The method of substitution, however, can be done with a more efficient time than the graph method. In addition, using substitution methods also minimizes errors due to scale inaccuracies when drawing completion graphs on chart methods.

After students master the substitution method, students learn to complete two-variable linear equation using elimination method which eliminating one of the variables to get the value of another variable. The elimination method used in the learning trajectory begins with a simple elimination method. It is easier for students to be able to directly eliminate one of the variables that already have the same coefficient value to get the value of another variable. The student's difficulty level was improved as students understood and were able to complete the two-variable linear equation using a simple elimination method. The next two-variable linear equation problem given to the student is not two-variable linear equation that can be directly eliminated, but requires additional step by multiplying one or both equations, so that one of the variables has the same coefficients. However, this is not a problem for students if the students have previously understood the concept of completing two-variable linear equation using a simple elimination method. 
The last method presented in the two-variable linear equation learning trajectory for junior high school students after students understand the concept of the previous methods is the mixed method. Students combine the elimination method to obtain the value of one variable and followed by substitution to get the value of the other variables. Although there are differences in two-variable linear equation problem-solving method, it will obtain the similar solution. The given problems are similar between methods, so that when encountering two-variable linear equation problems, students can choose the method to be used. In addition, the concept of integer and fractional operations is also used in two-variable linear equation regardless of the completion method used.

The final step is solving the two-variable linear equation problem. This step is given to students when the student has understood the completion of the two-variable linear equation concept, either solving using graphical methods, substitutions, elimination, or mixed method. The given problems have different levels of difficulty and variation. Gooding (2009: 35) mentioned that teachers can help students solve the mathematics problems by providing practice question to students and provide various problems that beyond the reach of students. The first problem given in this research is presented in pictures that can enable students to directly model the two linear equations. In this case, however, students still get help with the existence of tables that lead to the form two-variable linear equation. Besides, in this problem the students only given the question about the value of each variable, so that when the students get the second value of the variable then the student has answered the question of the problem. The level of difficulty in the second problem is more complex than the first problem. The question given on the second problem is not asked about the value of each variable but students need to recalculate according to the question given. The third problem is more complex than the second problem. The third problem is entirely in the form of a description without illustration or table, so that students must really understand the problem and write down the equation of the two variables based on the information given. The absence of picture illustration is very influential on the student's effort to understand the problem two-variable linear equation given. According to Hofe, Jordan, Hafner, Stölting, Blum \& Pekrun (2008: 58), images play important roles on mathematical problems. One of them is if the image does not fit with the concept, it will make student difficult in learning mathematics and vice versa. In addition, the use of decimal numbers and questions that cannot be answered directly by using the value of the obtained variables also plays an important role in the complexity of the third problem. The research results are in line with Retnawati (2017).

Mathematical skills are great of importance to be developed at a school; the modern economy, the management of its development, is one of the most actively developing aspects of the life of the community (Arpentieva et al., 2019). Based on the results of students' work in completing two-variable linear equation problems found that it is necessary to have learning trajectory, so that students will be easier in learning the concept of twovariable linear equation. The learning trajectory of two-variable linear equation includes modelling and deepening algebra and one-variable linear equation system, modelling two-variable linear equation system, solving problem by trial and error, completing two-variable linear equation with graphs, completing two-variable linear equation with simple substitutions, solving problem with simple elimination, solving problem with complex elimination, completing problem in a mixed method, and solving two-variable linear equation problems. In addition, learning trajectory also requires lesson plan and worksheet that is constructed based on learning trajectory as learning instruction to support learning implementation in understanding two-variable linear equation concept.

Cite this article as: Retnawati H., Sulistyaningsih E., Rasmuin R. (2020), How to Teach Mathematical Concept Easily? (Learning Trajectory of Two-Variable Linear Equation System Topic in Junior High School). Challenges of Science. Issue III, 2020. Pp.: 5-19. https://doi.org/10.31643/2020.001

\section{References}

Arends, R. I., \& Kilcher, A. (2010). Teaching for Student Learning Becoming an Accomplished Teacher. New York: Routledge. https://doi.org/10.4324/9780203866771

Arpentieva, M. R., Kassymova, G., Kenzhaliyev, O., Retnawati, H., Kosherbayeva, A. (2019). Intersubjective Management in Educational Economy. Challenges of Science. https://doi.org/10.31643/2019.004

Clements, D. H., \& Sarama, J. (2004). Learning Trajectories in Mathematics Education. Mathematical Thinking and Learning, 6(2), 81-89. https://doi.org/10.1207/s15327833mt10602_1 
Clements, D. H., \& Sarama, J. (2013). Rethinking Early Mathematics: What Is Research-Based Curriculum for Young Children? In L. D. English \& J. T. Mulligan (Eds.), Reconceptualizing Early Mathematics Learning, Advances in Mathematics Education, (pp. 121-147). Denver: Springer. https://doi.org/10.1 007/978-94-007-6440-8_7.

Daro, P., Mosher, F. A., \& Corcoran, T. B. (2011). Learning Trajectories in Mathematics: A Foundation for Standards, Curriculum, Assessment, and Instruction. https://doi.org/10.12698/cpre.2011.rr68

Dewi, A. P., Susanta, H., \& Listyorini, S. (2013). Analisis Pengendalian Kualitas Dengan Pendekatan P.D.C.A. (Plan-Do-Check-Act) Berdasarkan Standar Minimal Pelayanan Rumah Sakit Pada Rsud Dr. Adhyatma Semarang (Studi Kasus Pada Instalasi Radiologi). Journal Of Social And Politic, 1-12. https://doi.org/10.12928/si.v11i2.1657

Ferreira, D. H. L., \& Jacobini, O. R. (2009). Mathematical Modelling: From Classroom To The Real World. In M. Blomhøj \& S. Carreira (Eds.), Mathematical Application and Modelling in the Teaching and Learning of Mathematics (pp. 35-46).

Gooding, S. (2009). Children's Difficulties with Mathematical Word Problems. In M. Joubert (Ed.), Proceedings of the British Society for Research into Learning Mathematics, 29, (pp. 31-36).

Hujodo, H. (1998). Pengembangan kurikulum dan pembelajaran matematika. Malang: Universitas Negeri Malang.

Hofe, R. V., Jordan, A., Hafner, T., \& et al. (2009). On the Development of Mathematical Modelling Competencies The PALMA Longitudinal Study. In M. Blomhøj \& S. Carreira (Eds.), Mathematical Application and Modelling in the Teaching and Learning of Mathematics (pp. 47-60).

Kaur, B. \& Dindyal, J. (Eds). (2010). Mathematical application and modelling: yearbook 2010. Association of mathematicas educators. London: World Scientific Publishing.Co.Pte.Ltd.

Mendikbud. (2015). Peraturan menteri pendidikan dan kebudayaan Republik Indonesia nomor 5, tahun 2015 tentang kriteria kelulusan peserta didik, penyelenggaraan ujian nasional, dan penyelenggaraan ujian sekolah/madrasah/pendidikan kesetaraan pada SMP/MTS atau yang sederajat dan SMA/MA/SMK atau yang sederajat. https://doi.org/10.24832/jpnk.v17i6.58

O’Connell, Susan. (2007). Introduction to Problem Solving Grades PreK-2. Portsmouth: Heineman.

Pehkonen, E. (1987). The Meaning of Problem-solving for Children's Development. In: Articles on Mathematics Education (ed. E. Pehkonen), 71-86. University of Helsinki. Department of Teacher Education. Research Report 55.

Puspitasari, E., Yusmi, E., \& Nursangaji, A. (2015). Analisis Kesulitan Siswa Menyelesaikan Soal Cerita Materi Sistem Persamaan Linear Dua Variabel di SMP. Jurnal Pendidikan Dan Pembelajaran, 4(5), 1-9. https://doi.org/10.31764/pendekar.v1i1.282

Retnawati, H. (2017). Learning trajectory of item response theory course using multiple software. Olympiads in Informatics, 11, $123-142$. https://doi.org/10.15388/ioi.2017.10

Rindyana, B. S. \& Chandra, T. D. (2012). Analisis Kesalahan Siswa Dalam Menyelesaikan Soal Cerita Matematika Materi Sistem Persamaan Linear Dua Variabel Berdasarkan Analisis Newman. https://doi.org/10.36653/educatif.v1i1.3

Santoso, B., Nusantara, T., \& Subanji. (2013). Diagnosis Kesulitan Siswa Dalam Persamaan Linear Dua Variabel Serta Upaya Mengatasinya Menggunakan Scaffolding. In KNPM V, Himpunan Matematika Indonesia (pp. 491-503). https://doi.org/10.25134/jes-mat.v2i1.280

Seifi, M., Haghverdi, M., \& Azizmohamadi, F. (2012). Recognition of Students' Difficulties in Solving Mathematical Word Problems from the Viewpoint of Teachers. Journal of Basic and Applied Scientific Research, 2(3), 2923-2928.

Tan, Oon-Seng. (2004). Cognition, Metacognition, and Problem-based Learning. Tan (Eds). Enhancing Thinking Through Problem-Based Learning Approaches: International Perspectives. Singapore: Cengage Learning.

Wulandari, C. P., Hidayanto, E., \& Dwiyana. (2016). Analisis Kesulitan Siswa dalam Pemecahan Masalah Materi Sistem Persamaan Linear Dua Variabel. In Seminar Nasional Matematika Dan Pendidikan Matematika UNY 2016 (pp. 23-28). https://doi.org/10.31629/jg.v4i1.881

Wulandari, D., \& Harumi, E. (2014). Hasil Analisis Kesalahan Dalam Menyelesaikan Soal Sistem Persamaan Linear Peserta Didik SMK Antartika 1 Sidoarjo. Jurnal Pendidikan Matematika STKIP PGRI Sidoarjo, 2(1), 35-44.| https://doi.org/10.24252/auladuna.v5i1a9.2018 